\title{
Can overexpression of TGF- $\beta$ gene change the sex ratio in transgenic mice?
}

TSUng Hsiao Chien, Jie XU, Lu Xia XU, Xiu Lan LI, Wei KANG SHI, Zhen YAO

Shanghai Institute of Cell Biology, Chinese Academy of Sciences, Shanghai 200031, China.

\begin{abstract}
Mouse TGF- $\beta 1$ gene was microinjected into male pronuclei of F2 hybrid fertilized eggs obtained by mating CSJLF1 and C57BL/6J inbred strains to generate transgenic mice with over-expressed TGF- $\beta 1$ gene. The rate of founder production is $31 \%$ and Southern blot analysis of founder mice tail DNAs gave an integration efficiency of $33 \%$. TGF- $\beta 1$ gene could be stably integrated to the chromosomes of transgenic mice and transmitted to their progeny at a rate of $33 \%$ in the second generation. Dot blot analysis of tail RNA of some transgenic mice indicated a moderate expression of the transgene. The most interesting finding of the present work is the striking deviation from the normal male:female sex ratio in transgenic mice, with an average ratio of $6.7: 1$. The possible nature of the predominance of male sex in transgenic mice overexpressing TGF- $\beta 1$ is discussed.
\end{abstract}

Key words: Transgenic mice, over-expressed TGF- $\beta 1$ gene, MIS, sex ratio.

\section{INTRODUCTION}

Transforming growth factor- $\beta$ (TGF- $\beta$ ) is considered to be the prototype of a large family of secreted signaling peptides known as TGF- $\beta$ superfamily, including, besides TGF- $\beta$ itself, activins, bone morphogenetic factors, Muellerian inhibiting substance as well as many other factors. These factors are thought to be mediators playing key role in the control of cell proliferation, differentiation and development[1, 2]. This view is mostly substantiated by the large amount of evidences derived from 
the studies of TGF- $\beta 1$, pertaining to its structure, multiple biological activities, receptors and receptor-mediated signaling (for review see $[1,3,4,5,6]$ ). During mammalian embryogenesis, the studies of the expression patterns of TGF- $\beta \mathrm{S}$ have already yielded valuable informations, suggesting their importance in morphogenetic events[1]. But since the advent of ES cell technology, it is now possible to transfer any gene to stem cells and mice to define more closely the role of that particular gene in development, through either the "loss of function" or the "gain of function" approaches[7]. In the case of TGF- $\beta 1$ gene, the mice homozygous for null mutations generated from the targeted disruption of TGF- $\beta 1$ gene by homologous recombination developed multifocal inflammatory disorder in many organs that led to premature death[8, 9]. Transgenic mice with overexpressed TGF- $\beta 1$ gene have also been created. In general, the fate of the transgenic mice depends on the promoter and target tissue selected. With promoter of broad tissue expression, e.g. metallothionen promoter, the transgenic mice often showed embryonic or perinatal lethality, indicating that too much TGF- $\beta 1$, just like TGF- $\beta 1$ deficiency, is lethal; while using more restricted promoter, tissue specific effects of TGF- $\beta 1$ overexpression can be manifested, ranging from growth inhibition, developmental abnormalities or even to premature death[10,11].

Recently, we have established ES cell lines with overexpressed TGF- $\beta 1$ gene (ES-T cell lines) by introducing porcine TGF- $\beta 1$ gene into mouse ES-5 cells. The induced differentiation in vitro of ES-T6 cells with $10^{-9} M$ retinoic acid which gave rise exclusively to endothelial cells and vascular structures is causally related to the action of overexpressed TGF- $\beta 1$ polypeptide[12]. In the present paper, some interesting, but yet unexplicable effect of the overexpressed TGF- $\beta 1$ gene on the sex ratio in transgenic mice generated by the microinjection of mouse TGF- $\beta$ gene into male pronuclei of fertilized eggs will be presented.

\section{MATERIALS AND METHODS}

\section{Plasmid, DNA and probe}

Plasmid construct, pSV TGF- $\beta 1$, containing the full length of mouse TGF- $\beta 1 \mathrm{cDNA}(1.6 \mathrm{~Kb})$ was a gift from Dr. H. L. Moses of Vanderbilt University, USA[13] (Fig 1). 6.4 Kb plasmid DNA was prepared by the alkaline lysis method[14] . The purified DNA was solublized in $\mathrm{pH} 7.410 \mathrm{mM}$ Tris-0.1 $M$ EDTA, diluted to $1-2 \mu \mathrm{g} / \mathrm{ml}$ and linearized by XhoI digestion before microinjection. Plasmid DNA without TGF- $\beta 1$ cDNA insert was used as control. TGF- $\beta 1$ cDNA probe for Southern and RNA dot blot analysis was obtained from the construct by EcoR1 digestion.

\section{Animals}

Hybrids from matings between inbred strains CSJLF1 and C57BL/6J (referred to as SJL1/C57 mice) were used for the generation of transgenic mice. Hybrids from matings between inbred strains Balb/CBYJ and ICR/JCL (referred to as Balb/ICR mice) were served as pseudopregnant recipients.

\section{The production of transgenic mice}

The general procedures to generate transgenic mice were basically adhered to the instructions 
given by Hogan et al.[15].

DNA microinjection and embryo transfer: With Leitz micromanipulator 1-2 pl $(1-2 \mu \mathrm{g} / \mathrm{ml})$ of TGF- $\beta$ gene cDNA was microinjected into each male pronucleus of $\mathrm{F} 2$ hybrid fertilized eggs (or zygotes) generated from matings between $\mathrm{F} 1$ hybrid male and female SJL1/C57 mice. Injected eggs were then cultured overnight in $\mathrm{M} 16$ medium in $37^{\circ} \mathrm{C}$ incubator under $5 \% \mathrm{CO}_{2}$ atmosphere. 2celled embryos in good condition were selected in the next morning, washed with M16 medium twice and transferred into the oviducts of pseudopregnant F1 Balb/ICR female mice prepared beforehand.

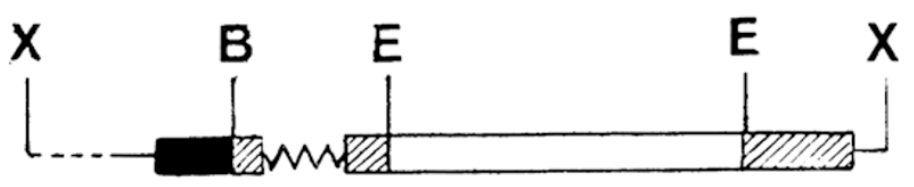

Fig 1. Genetic map of the pSV TGF- $\beta 1$ construct: The mouse TGF- $\beta 1$ cDNA was ligated into the EcoR 1 sites of pKCR3.

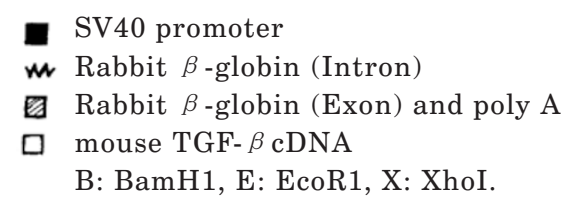

Screening of the potential transgenic mice: $1.6 \mathrm{~Kb}$ probe of TGF- $\beta 1 \mathrm{cDNA}$ was dissolved in $\mathrm{pH}$ $7.410 \mathrm{~m} M$ Tris-0.1 $M$ EDTA buffer at a concentration of $0.2 \mu \mathrm{g} / \mu \mathrm{l}$ and labeled with ${ }^{32} \mathrm{P}-\mathrm{dCTP}$ by random primer method as supplied by the manufacturer (Life Technol. Cat. No. 18187-013) to a relative radioactivity of $1.76 \times 10^{8} \mathrm{cpm} / \mu \mathrm{g}$.

Founder mice were screened for the presence of the transgene by restriction enzyme digestion and Southern blot analysis of their tail DNAs. 1-2 cm piece of a tail was excised, put into liquid N2, minced and DNA extracted by the phenol method. This was followed by EcoR1 digestion, agarose electrophoresis and Southern hybridization with radioactive $1.6 \mathrm{~kb}$ probe by the standard method[14].

In some cases, RNA dot blot analysis was also performed using total RNAs prepared from individual mouse tail by guanidium isothiocyanate-phenol-chloroform extraction[16].

\section{RESULTS AND DISCUSSION}

\section{The generation of transgenic mice with TGF- $\beta 1$ gene}

Pronuclei injection, embryo transfer and transgene screening: In a trial experiment, 33 pronuclei of F2 hybrid zygotes of SJL1/C57 mice were injected each with 1-2 $\mathrm{pl}$ of TGF- $\beta 1 \mathrm{cDNA}$, and incubated overnight in $37^{\circ} \mathrm{C}$ incubator. 13 survived 2-celled embryos were obtained with a survival rate of $40 \%$.

In the experiment followed, about $200 \mathrm{~F} 2$ hybrid zygotes of SJL1/C57 mice were injected with TGF- $\beta 1 \mathrm{cDNA}$, giving a total of 482 -celled embryos. 12 of these survived 2-celled embryos were then transferred separately into each oviduct of two F1 Balb/ICR hybrid pseudopregnant recipients, and later gave birth to two litters comprising 15 founders (9 male, 6 female). The rate of founder production was $31 \%$. The external morphology of these founders was quite normal, except their coat color 
Overexpression of TGF- $\beta 1$ gene in transgenic mice

was different from their pseudopregnant mothers.

Southern blot analysis of tail DNA was shown in Fig 2, in which 5 (No. 1, 2, 4; 11,12 ) out of 15 founders gave positive signal with labeled TGF- $\beta 1 \mathrm{cDNA}$. It must also be added that these 5 transgenic mice were all of male sex. The integration efficiency of TGF- $\beta 1$ gene was $33 \%$, a figure comparable to the data (10-40\%) for other genes studied by various worker in early and mid-eighties[15]. The relatively high integration efficiency of TGF- $\beta 1$ gene might possibly indicate that, in our cases, most of the integration may have been taken place in the one-celled embryos.

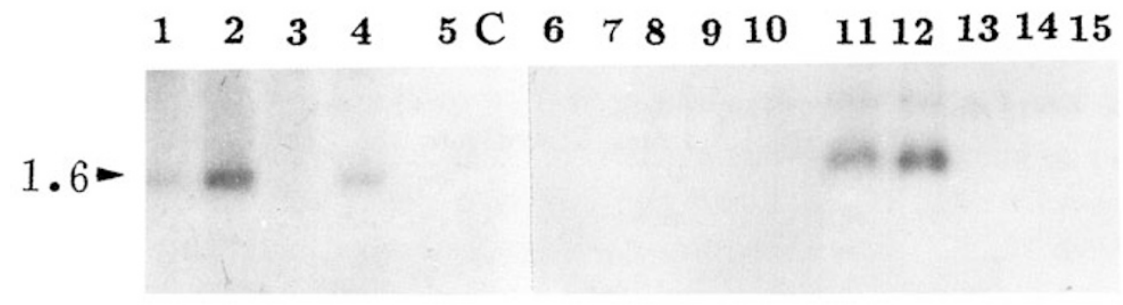

Fig 2. Southern blot analysis of tail genomic DNA from 15 founders (first generation). Tail DNA preparations were digested with EcoR1 and hybridized with $1.6 \mathrm{~Kb}$ TGF- $\beta 1$ probe.

No. 1, 2, 4, 11, 12 showed positive signals. C: genomic DNA of normal mouse tail as negative control.

The transmission of transgene to their progeny: In order to test the transmission of the integrated extra mouse TGF- $\beta 1$ gene to their offsprings, three transgenic male mice (No. 2, 11, 12 in Fig 2) with stronger hybridization signal were mated separarely with F1 hybrid SJL1/C57 female mice. Altogether 48 littermates (28 males and 20 females) were obtained from these matings. Primary Southern blot screening of these mice indicated that 20 of them displayed various degree of hybridization signals. Since the data were collected from different groups of littermates and at different time, Southern blot analysis of tail DNAs of these twenty mice was checked once again. 13 males and 3 females were finally shown to be transgenic mice (Fig 3 ), but the hybridization signals in three female mice (arrow-head indicated) were much weaker than their male counterparts. The result of this experiment pointed out clearly that TGF- $\beta 1$ gene can be stably integrated to the chromsomes of transgenic mice and transmitted to their progeny at a fairly high rate, about $33 \%$ to the second generation.

Later, we have made a mating between two transgenic mice (No. 11 male in Fig 2 with No. 7 female in Fig 3) to see what will be the transmission of the transgene in their progeny. This mating gave birth to a litter with 8 male and 7 female mice, but only two male mice showed distinct positive hybridization signals (Fig 4). The genetic background of these two transgenic mice was not identical, because No. 7 
female transgenic mice was originally derived from No. 2 male transgenic founder instead of No. 11 male transgenic founder in Fig 2. However, since all these male transgenic founders with stronger hybridization signals could transmit the transgene to their offsprings as mentioned above, the rather low rate of transmission in this group was quite unexpected. Whether this is due to the instability of the integrated transgene in later generation, cannot be said with certainty.

Fig 3. Southern blot analysis of tail genomic DNA of 20 primarily selected positive samples from 48 F2 littermates. The genomic DNAs were digested with EcoR1 and hybridized with 1.6 Kb TGF- $\beta 1$ probe. 13 males and 3 females ( $\boldsymbol{\Delta}$ ) showed positive signals.

S: $p S V$ TGF- $\beta 1$ positive control.

C: genomic DNA of normal mouse as negative control.

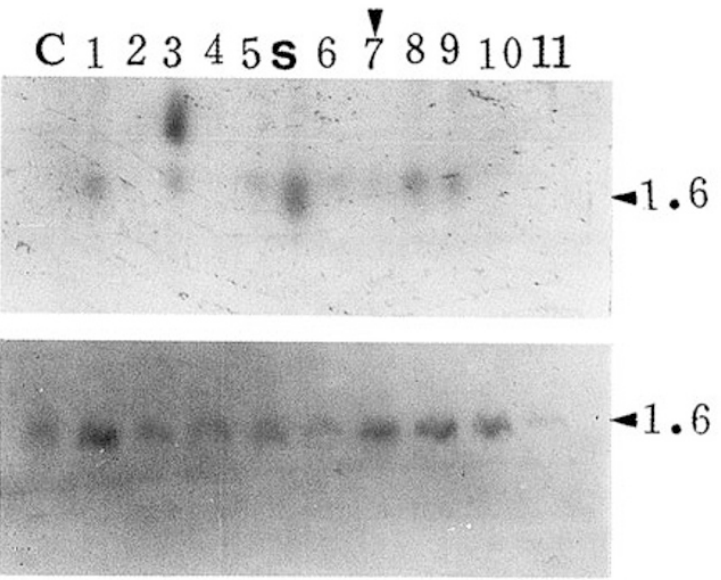

12 S 1314151617181920

\section{$\begin{array}{llllllllll}0 & 1 & 2 & 3 & 4 & 5 & 6 & 7 & 8 & 9\end{array}$}

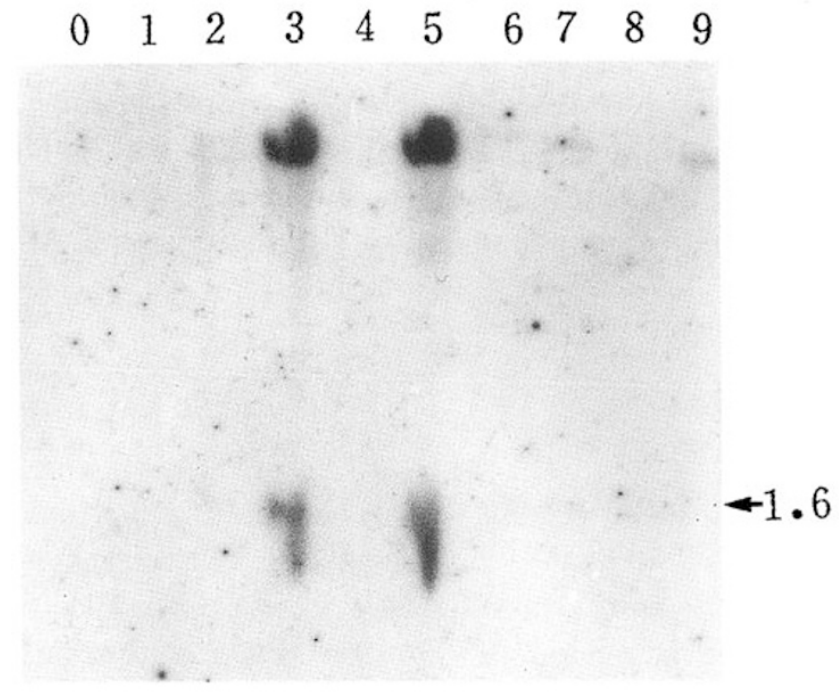

Fig 4. Southern blot analysis of tail DNA from 15 littermates derived from a cross between two transgenic mice, with only 2 males (No. 3, 5) showing positive signals. The negative results of mice No. 10-15 were not included. 0 : genomic DNA from normal mouse. 


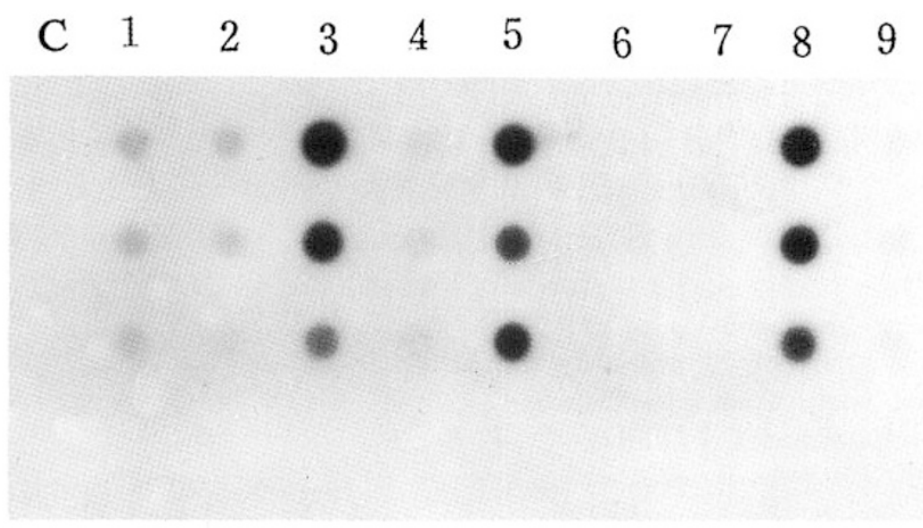

Fig 5. Dot blot analysis of tail total RNA from six $F_{3}$ (Fig 4. No. 1-6) and three $\mathrm{F}_{2}$ (Fig 3. No. 12-14) mice. For each mouse, the total RNA loaded was 20, 10 and $5 \mu \mathrm{g}$ respectively and then hybridized with ${ }^{32} \mathrm{P}$ dCTP labeled $1.6 \mathrm{~Kb}$ TGF- $\beta$ l probe. 3 males (No. 3, 5, 8) showed positive signals. C: total RNA of normal mouse tail as negative control.

In addition, we have taken nine mice at random, including three male transgenic mice of the second generation (Fig 3, No. 12-14) and other six mice of the last experiment (Fig 4, No. 1-6) to isolate total RNA from their tail and made dot blot hybridization with ${ }^{32} \mathrm{P}$-labeled TGF- $\beta 1$ probe. Among the five male transgenic mice, only three of them (two from No. 3 and 5 in Fig 4 and one from No. 13 in Fig 3) gave strong hybridization signals (Fig 5). The negative reaction of two other transgenic male mice (Fig 3, No. 12, 14) may possibly be due to some technical errors occurred during sample loading. Nevertheless, the strong signal in transgenic male mice made it clear that the integrated transgene is, at the least, moderately expressed in them, which is generally true for gene transfer and expression in mammalian cells with SV40 promoter.

The possible influence of the overexpression of TGF- $\beta 1$ gene on the sex ratio of transgenic mice

In the present study, one thing which is quite striking to us is the finding that most of transgenic mice obtained were belonged to male sex. Altogether, 23 transgenic mice so far generated were comprised of 20 males and 3 females, giving a sex ratio of 6.7:1. This figure is an average sex ratio of 3 experiments. But if we make comparison of the results of the matings between different individual transgenic mouse, the sex ratio of transgenic mice in their progeny obtained from an individual mouse can be higher or lower than the above figure, depending on the size and number of litters analyzed. As shown in Tab 1, the mating between No. 2 male transgenic mouse 
in Fig 2 and four F1 hybrid SJL1/C57 females has given a total of 29 littermates, with a sex ratio of 2.6 (male):1 (female) and a very high sex ratio deviation of 8 (male):1 (female) in transgenic mice. The tendency for the predominance of male sex in this group is highly revealable. However, the sex ratios of littermates actually born in 3 experiments were not so much deviated from the normal 1:1 ratio. For example, in the first experiment for the generation of transgenic mice, the sex ratio in the founder mice was 1.5 (male): 1 (female), but only 5 out of nine male founders were shown to be transgenic. Similar situation happened in the mating experiment between transgenic male mice with normal F1 hybrid females and in the mating experiment between two transgenic mice.

Now, the question is what is the cause of the predominance of male sex in transgenic mice? Is it due to the effect of over-expressed TGF- $\beta 1$ gene on the sex differentiation in early embryonic stages or due to some other unknown mechanism? In order to analyze this question, we need first to consider some related events. In the first place, Muellerian inhibiting substance (MIS), also known as anti-Muellerian hormone $(\mathrm{AMH})$, is the factor that causes the regression of the primordium of female genitalia, the Muellerian duct, in mammalian male embryo and has many other effects on sex development[17]. Secondly, MIS, as a member of TGF- $\beta$ superfamily[1, 2], is a glycoprotein with a highly conserved c-terminal domain that shows marked homology with human TGF- $\beta$ [18], and can be cleaved by plasmin at the cterminus into a TGF- $\beta$ like fragment that possesses regressing activity to Muellerian duct[19]. Lastly, Muellerian duct regression induced by MIS is characterized by the development of complex epithelial-mesenchymal interaction which is very similar to the mode of action of TGF- $\beta$ on epithelial-mesenchymal system, and MIS has, thus, been considered as a masculinizing relative of TGF- $\beta$ [17].

Tab 1. Protocol of the mating between transgenic male mouse No. 2 and four normal $F_{1}$ hybrid SJL1/C57 female mice

\begin{tabular}{ccccc}
\hline Female & \multicolumn{2}{c}{ No. Littermates born } & \multicolumn{2}{c}{ No. Transgenic mice } \\
\cline { 2 - 5 } mouse No. & male & female & male & female \\
1 & 6 & 3 & 2 & - \\
2 & 5 & 1 & 2 & - \\
3 & 5 & 1 & 2 & - \\
4 & 5 & 3 & 2 & 1 \\
Total & 21 & 8 & 8 & $8: 1$ \\
Sex ratio & \multicolumn{2}{c}{$2.6: 1$} & \multicolumn{2}{c}{ Transmission efficiency $31 \%$} \\
\hline
\end{tabular}

Nevertheless, in spite of some structural homology between MIS and TGF- $\beta$, there is no direct evidence, as far as we can aware, that TGF- $\beta$ can mimic certain biological activities of MIS or vice versa. In the present work, the transgenic mice were all dissected and the gross morphology of their reproductive system examined, but apparently they all looked normal. Moreover, one of female transgenic mice so far mated was proved to be fertile. Thus, there is no indication of aberrant pheno- 
types in a few female transgenic mice obtained in the present work, as those that have been observed in the transgenic mice overexpressing human MIS gene with metallothionen-1 promoter, where the inhibition of Muellenian duct differentiation led to sterile female without uteri, oviducts or ovaries[20]. But we are of the opinion that the possible effect of over-expressed TGF- $\beta 1$ on early mouse embryonic development, including its effect on sexual development could not be totally dismissed at the moment, and needs further investigation. In addition, from the data shown in Tab 1, we wonder whether the deviation of sex ratio in favor of male predominance could also be possibly due to the selective intrauterine death of some female embryos under particular circumstances, in which TGF- $\beta 1$ might play a direct and/or an indirect role. Experiments designed to throw some light on this question, such as the in vivo effect of TGF- $\beta 1$ on early embryos in pregnant females and in vitro effect of TGF- $\beta 1$ on the growth and differentiation of mouse uro-genital primordia. etc., are being considered.

\section{ACKNOWLEDGEMENT}

This project was supported by the National Natural Sciences Foundation of China, No:39180021.

\section{REFERENCES}

[1] Massague J. The transforming growth factor- $\beta$ family. Ann Rev Cell Biol 1990; 6:597-641.

[2] Kingsley DM. The TGF- $\beta$ superfamily: New members, new receptors and new genetic tests of function in different organisms. Genes Dev 1994; 8:133-46.

[3] Barnard JA, Lyons RM, Moses HL. The cell biology of transforming growth factors. Biochem Biophys Acta 1990; 1032:79-87.

[4] Roberts AB, Sporn MB. The transforming growth factor-betas. In "Peptide growth factors and their receptors". Eds MB Sporn and Roberts AB, Springer-Verlag, Berlin 1990; pp. 419-72.

[5] Derynck R. TGF- $\beta$-receptor-mediated signaling. TIBS 1994; 19:548-53.

[6] Attisano L, Wrana JL, Lopez-Casillas F, Massague J. TGF- $\beta$ receptors and actions. Biochem Biophys Acta 1994; 1222:71-80.

[7] Wagner EF. On transferring genes into stem cell and mice. The EMBO J 1990; 9:3025-32.

[8] Shull MM, Ormsby I, Kier AB, et al. Targeted disruption of the mouse transforming growth factor- $\beta 1$ gene results in multifocal inflammatory disease. Nature 1992; 359:693-9.

[9] Kulkarui AB, Huh CG, Becker D, et al. Transforming growth factor $\beta 1$ null mutation in mice causes excessive inflammatory response and early death. Proc Natl Acad Sci USA 1993; 90:7704.

[10] Sporn MB, Roberts AB. Transforming growth factor- $\beta$, recent progress and new challenges. J Cell Biol 1992; 119:1017-21.

[11] McCarteny-Francis NL and Wahl SM. Transforming growth factor $\beta$ : a matter of life and death. J Leuk Biol 1994; 55:401-9.

[12] Tsung H-C, Xia S-H, Xu L-X, Li X-L, Shi W-K, Yao Z. Expression of exogeneus porcine transforming growth factor- $\beta 1$ gene in ES cells and its effect on their differentiation in vitro. Acta Biol Expt Sinica 1995; 28:173-89.

[13] Torre-Amione G, Beauchamp RD, Koeppen H, et al. A highly immunogenic tumor transfected with a murine transforming growth factor type/ $\beta 1 \mathrm{cDNA}$ escapes immune surveillance. Proc 
Tsung HC et al.

Natl Acad Sci USA 1990; 87:1486-90.

[14] Sambrook J, Fritsch EF, Maniatis T. Molecular cloning, A Laboratory manual. 2nd ed. New York CSH 1989.

[15] Hogan B, Costantini F, Lacy E. Manipulating the mouse embryo: A laboratory manual. Sections B. C. D. New York. CSH, 1986.

[16] Chemczynski P, Succhi N. Single step method for RNA isolation by acid guanidium thiocyanatephenol-chloroform extraction. Anal Biochem 1987; 162:156-59.

[17] Josso N. Anti-Muellerian hormone: a masculinizing relative of TGF- $\beta$, in "Oxford Reviews of Reproductive Biology". Ed Charlton HM, Vol 16:139-63. Oxford University Press 1994.

[18] Cate RL, Mattaliano R J, Hession C, et al. Isolation of the bovine and human gene for Muellerian inhibiting substance and expression of the human gene in animal cells. Cell 1986; 45:685-98.

[19] Pepinsky RB, Sinclair LK, Chow EP, et al. Proteolytic processing of Muellerian inhibiting substances produces a transforming growth factor- $\beta$ like fragment. J Biol Chem 1988; 263:18961-5.

[20] Behringer RR, Cate RL, Froelick GJ, et al. Abnormal Sexual development in transgenic mice chronically expressing Muellerian inhibiting substance. Nature 1990; 345:167-70.

Received 22-4-1996. Revised 7-5-1996. Accepted 22-5-1996. 